\title{
PENGEMBANGAN MEDIA PEMBELAJARAN DENGAN SOFTWARE LECTORA UNTUK MATAKULIAH WORKSHOP DAN FINISHING KAYU
}

\author{
Mohammad Musthofa Al Ansyorie ${ }^{1}$, Eko Suwarno ${ }^{2}$, Antelas Eka Winahyo ${ }^{3}$, Priyono ${ }^{4}$, Rahmad Basofi ${ }^{5}$, \\ Eko Suwarno ${ }^{2}$ \\ Teknik Sipil, Fakultas Teknik, Universitas Negeri Malang \\ Jalan Semarang No 5, Kota Malang, Jawa Timur 65145 \\ (0341)551-312 \\ E-mail: musthofansyorie.ft@um.ac.id
}

\begin{abstract}
ABSTRAKS
Perkembangan era revolusi industri 4.0 saat ini sangat terasa, termasuk dalam bidang pendidikan. Seperti yang diutarakan oleh Ibrahim (2018) yang menyatakan banyak aspek yang dapat mengubah cara berpikir manusia di era digital, karakteristik yang muncul di dunia digital abad 21 antara lain civitas akademika harus selalu menjelajah jejak teknologi, berbagi dalam menciptakan ide dan ilmu yang akan dibuat, berinteraksi serta berkolaborasi dalam hal sosial dengan memandang berbagai aspek yang akan diterapkan. Salah satu alat bantu dalam pengembangan media pembelajaran yang dapat memnuhi kriteria tersebut adalah Lectora. Penyelesaian masalah dalam penelitian ini menggunakan model penelitian dan pengembangan media menurut Borg dan Gall dalam Sugiyono (2010:409) dengan memodifikasi sesuai dengan keperluan penelitian ini. Modifikasi yang dimaksud dalam hal ini adalah tahapan dalam pengembangan media pembelajaran yang meliputi: (1) penelitian dan pengumpulan informasi awal; (2) perencanaan media; (3) pengembangan produk awal; (4) validasi ahli; (5) analisa dan revisi produk akhir. Berdasarkan hasil uji validasi media secara keseluruhan menunjukkan hasil sangat valid dengan nilai prosentase $88,5 \%$ dan untuk uji validasi materi yaitu terkategorikan sangat valid dengan prosentase $85,0 \%$.
\end{abstract}

Kata Kunci: pengembangan, media pembelajaran, lectora, finishing kayu

\begin{abstract}
The development of the industrial revolution era 4.0 is currently very pronounced, including in the field of education. As stated by Ibrahim (2018) who states that there are many aspects that can change the way humans think in the digital era, the characteristics that emerge in the digital world of the 21st century include the academic community that must always explore traces of technology, share in creating ideas and knowledge to be created, interact and collaborate in social matters by looking at various aspects that will be applied. One of the tools in the development of instructional media that can meet these criteria is Lectora. The solution to the problem in this study uses a media research and development model according to Borg and Gall in Sugiyono (2010: 409) by modifying it according to the needs of this study. The modifications referred to in this case are the stages in the development of learning media which include: (1) research and initial information gathering; (2) media planning; (3) initial product development; (4) expert validation; (5) analysis and revision of the final product. Based on the results of the media validation test as a whole, it shows very valid results with a percentage value of $88.5 \%$ and for the material validation test, which is categorized as very valid with a percentage of $85.0 \%$.
\end{abstract}

Keywords: development, learning media, lectora, wood finishing

\section{PENDAHULUAN}

\subsection{Latar Belakang}

Perkembangan era revolusi industri 4.0 saat ini sangat terasa, termasuk dalam bidang pendidikan. Seperti yang diutarakan oleh Ibrahim (2018) yang menyatakan banyak aspek yang dapat mengubah cara berpikir manusia di era digital, karakteristik yang muncul di dunia digital abad 21 antara lain civitas akademika harus selalu menjelajah jejak teknologi, berbagi dalam menciptakan ide dan ilmu yang akan dibuat, berinteraksi serta berkolaborasi dalam hal sosial dengan memandang berbagai aspek yang akan diterapkan. Sejalan dengan hal tersebut pula, Riyana (2018) menyampaikan bahwa tantangan pendidikan di era revolusi industri 4.0 berupa perubahan dari cara belajar, pola berpikir serta cara bertindak para peserta didik dalam mengembangkan inovasi kreatif berbagai bidang.

Di zaman sekarang ini penyesuaian proses pembelajaran terhadap perkembangan tekhnologi yang signifikan dapat dilakukan dengan menyiapkan materi pembelajaran yang disampaikan dengan memanfaatkan media pembelajaran yang terkini (digitalisasi). Penggunaan komputer sebagai media pembelajaran dapat divariasikan dalam beberapa bentuk seperti teks, slide, animasi, video, maupun audio visual yang berbasis digital. Penerapan materi pembelajaran dengan menggunakan penggabungan 
variasi bentuk tersebut lebih dikenal dengan istilah multimedia pembelajaran. Menurut Arsyad (2002) multimedia pembelajaran merupakan penggabungan dari beberapa bentuk menjadi suatu kesatuan yang menampilkan informasi, pesan atau isi pelajaran.

Penggunaan media pembelajaran yang berbasis digital sangat diperlukan disemua jenjang pendidikan dan semua materi yang akan disampaikan. Termasuk dalam hal ini bagi proses pembelajaran di Jurusan Tekni Sipil FT UM, khususnya untuk matakuliah Workshop dan Finishing Kayu. Dimana pada matakuliah ini, mahasiswa sering mengalami kesulitan dalam memahami materi yang dibuat dalam bentuk lembaran-lembaran teks dan presentasi menggunakan software presentasi yang umum digunakan. Oleh karena itu, dibutuhkan suatu media pembelajaran yang memiliki unsur terkini, atraktif, mudah dalam penggunaan, dan lebih bervariasi.

Salah satu alat bantu dalam pengembangan media pembelajaran yang dapat memnuhi kriteria tersebut adalah Lectora. Penggunaan software lectora ini dikalangan pendidik yang tidak memiliki background Teknologi Pembelajaran tentunya sangat asing. Sedangkan, software ini sendiri memiliki beberapa keunggulan yang dapat digunakan sebagai alat bantu pengembangan media pembelajaran.

\subsection{Referensi}

a. Media Pembelajaran

Purwono, dkk. (2014) menjelaskan bahwa media pembelajaran memiliki peranan penting dalam menunjang kualitas proses pembelajaran yang dapat membuat pembelajaran lebih menarik dan menyenangkan. Seperti yang sampaikan oleh Omodara (2014: 6) yaitu "Educational media refers to channels of communication that carry messages with an instructional purpose. They are usually utilized for the sole purpose of learning and teaching" yang artinya media pendidikan merujuk pada saluran komunikasi yang membawa pesan untuk tujuan pembelajaran. Hal tersebut sejalan dengan pendapat Adam \& Syastra (2015) menjelaskan bahwa media pembelajaran adalah segala sesuatu baik berupa fisik maupun teknis dalam proses pembelajaran untuk membantu pendidik dalam mempermudah penyampaian materi pelajaran kepada siswa sehingga tujuan yang akan dicapai menjadi mudah dan terumuskan.

Berdasarkan pengertian tersebut dapat disimpulkan bahwa media pembelajaran merupakan alat bantu dalam proses pembelajaran untuk merangsang pikiran, perasaan, perhatian, dan kemampuan atau keterampilan pembelajar sehingga dapat mendorong terjadinya proses belajar yang lebih menarik dan menyenangkan. Alat bantu berupa media pembelajaran tersebut diharapkan dapat menunjang proses pembelajaran dengan mudah.

1. Kegunaan Media Pembelajaran
Peran pembelajaran adalah menyediakan, menunjukkan, membimbing dan memotivasi para pembelajar agar mereka dapat berinteraksi dengan berbagai sumber belajar yang ada. Bukan hanya sumber belajar yang berupa orang, melainkan juga sumber-sumber belajar lain untuk meningkatkan kemampuan dalam belajar diantaranya dengan memanfaatkan fungsi media pembelajaran (Falahudin, 2014). Sedangkan menurut Sumberharjo, dkk. (2015) menjelaskan bahwa media mengandung pesan sebagai perangsang belajar dan dapat menumbuhkan motivasi belajar sehingga siswa tidak bosan. Peranan atau kegunaan media pembelajaran dibagi menjadi tiga proses belajar antara lain: 1) siswa memiliki kemampuan untuk menangkap pembelajaran dengan baik lewat penggunaan media dalam pengajaran di kelas, hal ini dikarenakan media pembelajaran menjadi sumber belajar yang memungkinkan siswa dapat memperoleh pengetahuan ataupun sikap, 2) media membangkitkan keinginan dan minat siswa untuk belajar dan membawa pengaruh positif bagi psikologis siswa dikarenakan media pembelajaran dapat memperlancar interaksi antara guru dengan siswa, 3) Media memiliki kemampuan untuk menampilkan kembali objek atau kejadian dengan berbagai macam cara dengan menyesuaikan keperluan.

Sidik (2018) menambahkan peranan atau kegunaan media pembelajaran dalam proses pembelajaran: 1) memperjelas penyajian materi agar tidak hanya bersifat verbal (dalam bentuk tulisan), 2) mengatasi keterbatasan ruang, waktu, dan daya indera, 3) penggunaan media secara tepat dan bervariasi dapat mengatasi sifat pasif anak didik, 4) menghindari kesalahpahaman terhadap suatu objek dan konsep, dan 5) menghubungkan yang nyata dengan yang tidak nyata. Berdasarkan penjelasan diatas dapat dikaji bahwa media pembelajaran memiliki peranan dan kegunaan yang berpengaruh terhadap pengajaran di dalam kelas, karena dengan memanfaatkan media pembelajaran dapat menumbuhkan motivasi belajar yang tidak membosankan dan bervariasi.

2. Jenis Media Pembelajaran

Media pembelajaran saat ini memiliki jenis yang beragam sesuai dengan perkembangan teknologi yang ada dan memunculkan berbagai jenis inovasi media pembelajaran. Menurut Anandarasa (2019) media pembelajaran dapat digunakan sebagai bahan ajar yang inovatif untuk peserta didik. Berikut adalah jenis media pembelajaran inovatif antara lain.

a) Poster, merupakan media untuk menjelaskan suatu hal terkait materi pembelajaran untuk memantik pertanyaan atau diskusi yang tergolong konvensional namun ampuh dalam memvisualisasikan proses dan hasil belajar dimana referensi gambar dapat diambil dari internet, majalah, buku bekas, dll. Misal: 1) poster 
ajakan untuk menaati aturan berlalu lintas, atau 2) poster untuk menjelaskan hidup bersih dan sehat.

b) Papan atau buku interaktif, merupakan media yang dapat digunakan dalam pembelajaran dimana didalamnya terdapat interaksi dengan komponen didalamnya. Misal: 1) flipbook, atau 2) mading tiga dimensi.

c) Alat Peraga, merupakan media ajar yang implementasinya sangat beragam dikarenakan fungsinya yang memperagakan suatu pengetahuan atau materi. Misal: 1) alat peraga bentuk 3D untuk menjelaskan konsep bangun ruang, atau 2) alat peraga torso untuk menjelaskan bagian tubuh manusia.

d) Lagu, merupakan media yang digunakan untuk menyampaikan pesan kepada murid dan dapat dimanfaatkan untuk menjembatani komunikasi bersama peserta didik. Misal: 1) memodifikasi lagu daerah untuk proses perkenalan.

e) Video, merupakan media yang digunakan untuk pengajaran mulai dari video penjelasan atau tutorial, video pengetahuan berisi informasi, dan film yang memiliki durasi lebih panjang. Terdapat dua posisi dalam pemanfaatan media pembelajaran ini antara lain: 1) peserta didik sebagai konsumen, dan 2) peserta didik sebagai produsen. Peserta didik yang diposisikan sebagai konsumen dapat digunakan untuk sarana menyampaikan informasi, memantik rasa ingin tahu, dan bahan diskusi. Namun jika diposisikan sebagai produsen maka peserta didik dapat ditugaskan untuk menciptakan video berisi informasi tertentu seperti video reportase, dokumenter, atau film pendek.

f) Permainan, merupakan media yang menjadi andalan guru dalam menyampaikan materi dalam belajar karena lebih menyenangkan dan bermakna. Jenis permainan yang dapat digunakan untuk media pembelajaran antara lain: 1) permainan dalam bentuk aktivitas (gobak sodor, kucing-kucingan, petak umpet, engklek, dsb.), 2) permainan kartu atau papan (monopoli, ular tangga, halma), 3) permainan berbasis alat (gasing, egrang, balok warna warni, lego, boneka, dsb), 4) permainan yang bentuknya digital (playstation, tendo, game android). Tiga hal penting dalam memanfaatkan media dalam bentuk permainan antara lain: 1) pengarahan, 2) pendampingan, dan 3) refleksi.

g) Aplikasi berbasis teknologi, merupakan media yang proses pengembangannya sangat komplek yang pemanfaatannya sangat membantu proses belajar. Misal: 1) Duolinggo untuk belajar bahasa inggris, 2) Quizizz untuk assigment, dan 3) Kahoot! untuk interaksi pembelajaran). Kunci dari media ini terletak pada kesesuaian proses belajar dengan aplikasi yang digunakan.

3. Klasifikasi Media Pembelajaran

Media dan alat pembelajaran merupakan hal yang berbeda, akan tetapi masyarakat masih sering rancu dalam memahami perbedaan media dan alat pembelajaran. Pengertian media cenderung kepada benda lunak (software) yang berisi informasi pendidikan yang pada umumnya disampaikan melalui bantuan peralatan. Sedangkan peralatan merupakan benda keras (hardware) yang merupakan sarana untuk menampilkan informasi tersebut.

Klasifikasi media pembelajaran menurut Ibrahim (2014) yang diuraikan berdasarkan kerumitannya sebagai berikut.

a) Media non-proyeksi 2D, merupakan media yang mempunyai dimensi panjang dan lebar yang penggunanya tidak memerlukan bantuan perangkat proyeksi. Misal: 1) papan tulis, 2) papan putih maknetis ataupun elektronik, 3) papan flanel, 4) alat lebar gantungan (ALG), 5) alat lebar sampingan (ALS), 6) poster, 7) handouts, dan 8) visualisasi data.

b) Media non-proyeksi 3D, merupakan media yang mempunyai dimensi panjang, lebar, dan tinggi dimana penggunanya tidak memerlukan bantuan perangkat proyeksi. Misal: 1) Globe, 2) Torso, dsb.

c) Audio, merupakan bahan atau media yang mengandung pesan bentuk auditif (pita suara atau cakram suara) yang dapat merangsang pikiran, perasaan, perhatian, dan kemauan siswa, sehingga terjadi proses belajar. Misalnya adalah pembelajaran dalam lagu, mendengarkan musik yang berisi pengetahuan atau materi.

d) Proyeksi, merupakan salah satu media yang terklarifikasi pada media visual yang memberikan rangsangan melalui indera penglihatan dengan interaksi lewat pesan atau materi pelajaran yang ingin disampaikan.

e) Televisi, merupakan media elektronik yang mampu menayangkan gambar bergerak atau video. Menurut Azhar (2013: 53) dalam buku media pembelajaran ada banyak sekali keuntungan menggunakan televisi sebagai media pembelajaran antara lain sebagai berikut.

1) Telivisi dapat memancarkan berbagai jenis bahan audio-visual termasuk gambar-gambar diam, film, objek, spesimen, dan drama.

2) Televisi bisa menyajikan model dan contoh yang baik bagi siswa. 
3) Televisi dapat membawa dunia nyata ke rumah dan ke kelas-kelas, seperti orang, tempat-tempat, dan peristiwa melalui penyiaran langsung atau rekaman.

4) Televisi dapat memberikan kepada siswa peluang untuk melihat dan mendengarkan diri sendiri.

5) Televisi dapat menyajikan programprogram yang dapat dipahami oleh siswa dengan usia dan tingkatan pendidikan yang berbeda-beda.

6) Televisi dapat menyajikan visual dan suara yang amat sulit diperoleh pada dunia nyata.

7) Televisi dapat menghemat waktu guru dan siswa, disamping itu televisi merupakan cara yang ekonomis untuk menjangkau sejumlah besar siswa pada lokasi yang berbeda-beda untuk penyajian yang bersamaan.

f) Video, merupakan media pembelajaran yang memudahkan peserta didik dalam memahami pelajaran karena dapat mempengaruhi fikiran dan emosional serta mempermudah guru dalam menyampaikan materi dan dapat diulang kapan saja dengan materi yang sama dan pembelajaran yang sama.

g) Komputer, merupakan jenis media yang secara virtual dapat menyediakan respon yang segera terhadap hasil belajar yang dilakukan oleh peserta didik. Sajian multimedia berbasis komputer dapat dioptimalkan sebagai sarana untuk menampilkan dan merekayasa teks, grafik atau gambar, dan suara dalam sebuah tampilan yang terintegrasi. Tampilan tersebut yang akan digunakan untuk menyampaikan informasi atau materi sehingga lebih efektif untuk pembelajaran.

4. Kriteria Media Pembelajaran Ideal

Pemilihan media yang akan digunakan dalam kegiatan pembelajaran hendaknya sesuai dengan karakteristik siswa agar informasi yang disampaikan melalui media dapat dipahami oleh siswa dengan mudah. Menurut Arsyad (2013) menjelaskan bahwa kriteria pemilihan media bersumber dari konsep media pembelajaran yang merupakan bagian dari sistem instruksional secara keseluruhan. Adapun kriteria tersebut antara lain: 1) sesuai dengan tujuan, 2) praktik, luwes, dan bertahan, 3) mampu dan terampil menggunakan, 4) pengelompokan sasaran, 5) mutu teknis.

Penjelasan tersebut hampir sama dengan penjelasan dari Purwanti (2018) dimana terdapat sepuluh kriteria dalam menentukan media pembelajaran yang tepat serta ideal antara lain sebagai berikut. a) Sesuai dengan tujuan yang akan dicapai, kehadiran media harus memiliki tujuan yang ingin dicapai agar dapat mendukung ketercapaian atas tujuan sebagai media komunikasi yang modern sehingga akan berkesinambungan dan terkoneksi antar keduanya.

b) Karakteristik media yang akan digunakan sesuai dengan proses pembelajaran.

c) Mampu mendukung isi dan bahan pembelajaran.

d) Media mudah diperoleh

e) Kemudahan dalam pengaksesan, kesukaran dalam mengakses media akan membuat penggunanya tidak bisa memanfaatkan media dengan baik dimana tujuan media yang seharusnya membantu proses pembelajaran.

f) Penggunaan tidak memakan waktu yang lama.

g) Kesesuaian media pembelajaran dengan cara berfikir siswa

h) Sesuai dengan situasi dan kondisi lingkungan

i) Sesuai dengan kemampuan para pengajar

j) Efektifitas penggunaan media dalam pembelajaran

Berdasarkan penjelasan tersebut dapat dikaji terkait dengan kriteria media pembelajaran yang ideal, yaitu media minimal harus memiliki kriteria yang sesuai dengan tujuan yang akan dicapai, mampu mendukung isi dan bahan pembelajaran, serta efektif atau menyingkat waktu dalam penggunaan media pembelajaran. Apabila media yang dikembangkan telah menunjukkan ciri atau kriteria diatas, maka media tersebut dapat dikategorikan sebagai media pembelajaran yang siap diimplementasikan kepada peserta didik dalam kelas.

\section{b. Software Lectora}

Menurut Mas'ud Muhammad (2012) Software Lectora inspire merupakan program aplikasi yang dapat digunakan untuk membuat presentasi maupun media pembelajaran. Software Lectora inspire dikembangkan oleh Trivanis Corporation yang merupakan Authoring Tool untuk pengembangan konten e-learning. Timothy D. Loudermilk merupakan pendiri software lectora di Cincinnati, Ohio, Amerika pada tahun 1999. Tahun 2000, Lectora menjadi yang pertama dalam sistem authoring AICC-bersertifikat di pasar. Kegunaan dari software tersebut diantaranya seperti: (1) menggabungkan flash, (2) merekam video, (3) menggabungkan gambar, (4) Screen Capture.

Lectora didesain khusus bagi pemula, sehingga keunggulan dari lectora inspire sangat mudah digunakan dalam pembuatan media pembelajaran dan dapat membuat materi uji atau evaluasi. Media yang dikembangkan dengan software lectora dapat 
dipublish secara online maupun offline, sehingga mempermudah para guru untuk melakukan penilaian dikarenakan sudah otomatis muncul skor. Adapun manfaat yang diperoleh dalam mengembangkan media pembelajaran dengan menggunakan Lectora antara lain sebagai berikut:

1. Guru dapat membuat dan menyajikan materi ajar dengan tanpa harus melakukan programming.

2. Guru dapat melakukan pengujian terhadap materi ajar yang diberikan, dalam berbagai macam bentuk tes seperti pilihan ganda, benar/salah, mencocokkan, tarik dan tempatkan, isian singkat, dan hot spot.

3. Guru/peserta didik dapat mengakses materi ajar/uji yang dibutuhkan baik secara offline maupun online.

4. Mampu menggunakan teks, suara, video, animasi dalam suatu kesatuan.

5. Mampu memvisualisasikan materi yang abstrak.

6. Membawa objek yang sangat besar atau berbahaya dalam lingkungan kelas.

7. Menampilkan objek yang tidak bisa dilihat oleh mata telanjang.

Penggunaan software Lectora yang digunakan sebagai pengembangan media pembelajaran elearning yang relatif mudah diaplikasikan dan diterapkan karena tidak memerlukan pemahaman bahasa pemrograman dimana mempunyai potensi besar untuk meningkatkan motivasi belajar peserta didik dibandingkan pembelajaran konvensional (Zuhri \& Rizaleni, 2016). Hal tersebut juga dibuktikan oleh penelitian sebelumnya bahwa penggunaan software Lectora terbukti valid, praktis, dan efektif dalam meningkatkan hasil peserta didik (Wiyono, 2015). Adapun Software Lectora menurut Sulastri (2016) yang digunakan untuk pengembangan media pembelajaran interaktif memiliki keunggulan antara lain: (1) digunakan sebagai media pembuat website, konten e-learning interaktif, dan presentasi (2) konten yang dikembangkan dengan perangkat lunak Lectora dapat dipublikasikan ke berbagai output seperti HTML, single file executable, CD-ROM, maupun standar e-learning seperti SCORM dan AICC (3) lectora kompatibel dengan berbagai sistem manajemen pembelajaran (LMS) (4) memiliki banyak sekali fitur yang dapat digunakan untuk pengembangan media sesuai dengan kebutuhan (5) Memiliki banyak template (6) didukung fasilitas aplikasi pendukung lain: Snagit, Camtasia, Flypaper (7) dapat membuat kuis dengan mudah. Beberapa keunggulan tersebut dapat dimanfaatkan sebagai bahan media pembelajaran terutama untuk pembelajaran berbasis praktik atau workshop.

c. Workshop dan Finishing Kayu

Menurut Kamus Besar Bahasa Indonesia (KBBI) pada Pusat Bahasa Depdiknas (2001) Workshop merupakan pelaksanaan berupa proses, cara, perbuatan melaksanakan (rancangan, keputusan, dan sebagainya). Pendapat lain juga mengemukakan mengenai pengertian workshop yaitu berupa pertemuan dalam penyampaian materi dengan persiapan yang matang, menguasai dengan baik serta memberikan contoh ilustrasi yang jelas (Nurani, 2003). Berdasarkan sifatnya workshop dibagi menjadi dua, yaitu mengikat dan bebas. Workshop mencakup beberapa hal, diantaranya: (1) merumuskan tujuan untuk memperoleh output/hasil akhir yang akan dicapai, (2) merumuskan pokokpokok masalah yang akan dibahas secara rinci yang dimaksudkan agar mempermudah proses berjalannya kegiatan, dan (3) menentukan prosedur pemecahan masalah (Rosmaryanti, 2010). Hal ini menunjukkan bahwa workshop adalah pertemuan orang yang bekerja sama dalam kelompok kecil dan dibatasi pada masalah yang dihadapi sendiri (Suprayekti, 2017).

Workshop dan finishing kayu merupakan sarana prasarana yang dimiliki suatu instansi lembaga pendidikan sebagai media serta wadah seperti macam-macam peralatan, kelengkapan, dan bendabenda untuk memudahkan penyelenggaraan pendidikan khususnya praktik kerja kayu (Bafadal, 2003). Semua pekerjaan dalam workshop dan finishing kayu yang berhubungan dengan proses belajar mengajar, memiliki materi pelajaran yang berkaitan dengan pembuatan, perakitan, penyusunan, pembongkaran, pemasangan, dan perbaikan perkakas (equipment) dan alat (tools) (Faris, 2018). Menurut Permendiknas No. 40 tahun 2008 menyebutkan mengenai kebutuhan dalam sarana prasarana dalam workshop dan finishing kayu antara lain: (1) memiliki bengkel pemesinan (2) rasio peserta didik (3) daya tampung ruang untuk peserta (4) penyimpanan dan insfrastruktur (5) perabot ruang bengkel kayu (6) media pendidikan di bengkel kayu (7) perlengkapan kerja kayu. Berdasarkan buku pengantar praktik bengkel kayu oleh Deny (2005) proses mata rantai kerja produksi khususnya dalam furniture workshop kayu secara keseluruhan antara lain: (1) desain (2) produksi (3) intermediasi (4) promosi dan marketing, dimana tahapan pada saat produksi merupakan tahapan yang kritis dikarenakan menyangkut modal kerja dalam bentuk upah, bahan baku, dan operasi mesin. Proses produksi sendiri terdiri dari: (1) pemilihan material (2) proses manufaktur (3) proses penyambungan.

\subsection{Metode Penelitian}

Penyelesaian masalah dalam penelitian ini menggunakan model penelitian dan pengembangan media menurut Borg dan Gall dalam Sugiyono (2010:409) dengan memodifikasi sesuai dengan keperluan penelitian ini. Modifikasi yang dimaksud dalam hal ini adalah tahapan dalam pengembangan media pembelajaran yang meliputi: (1) penelitian dan pengumpulan informasi awal; (2) perencanaan media; (3) pengembangan produk awal; (4) validasi 
ahli; (5) analisa dan revisi produk akhir. Secara rinci masing-masing langkah dalam penelitian dan pengembangan ini terbagi dalam tiga tahap yaitu tahap pendahuluan, tahap pengembangan produk, dan tahap pengujian produk. Sedangkan prosedur dalam penelitian pengembangan ini terdiri dari 3 tahap yaitu tahap pendahuluan, tahap pengembangan produk dan tahap pengujian produk. Secara sistematis dapat dilihat pada diagram alur penelitian pada Gambar berikut.

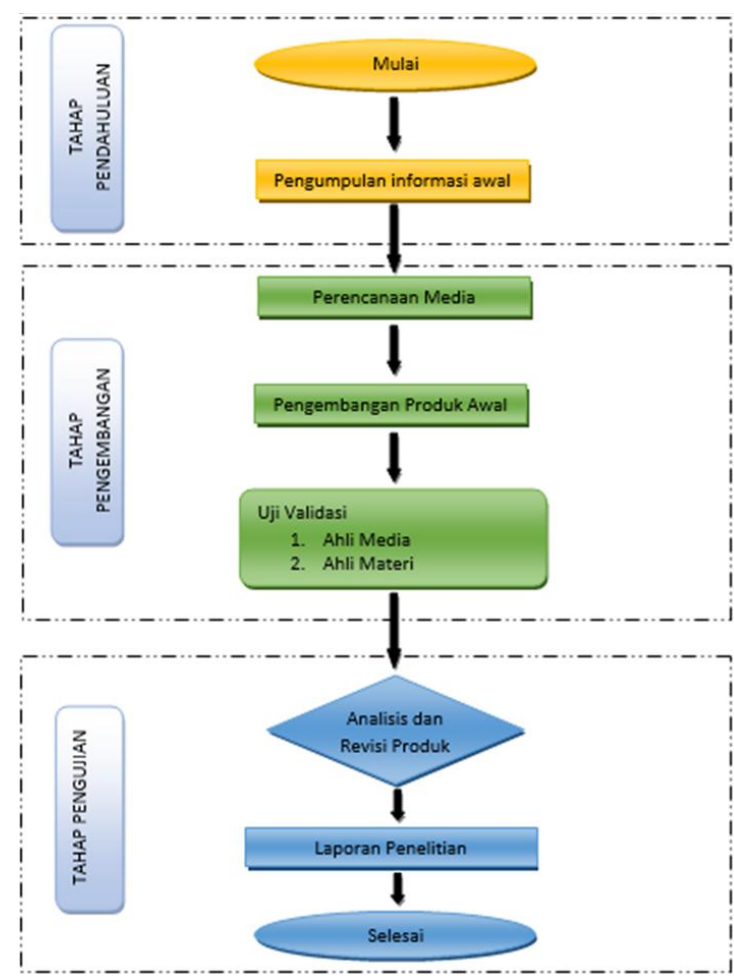

Gambar 1. Kerangka Alur Pengembangan

Analisa terhadap validasi media pembelajaran ini dianalisa secara deskriptif yang dilakukan dengan menghitung rata-rata hasil penilaian yang diberikan oleh ahli. Hasil penilaian ini akan didapatkan skor validasi. Skor Validasi merupakan hasil dari ratarata nilai yang diberikan oleh semua validator. Menurut Akbar dan Sriwijaya (2010:213) rumus yang digunakan untuk mengelolah data dari subyek pengguna dapat dilihat pada persamaan 1 .

$$
\mathrm{V}=\mathrm{TSEV} /(\mathrm{S}-\mathrm{max}) \times 100 \%
$$

Keterangan:

$$
\begin{array}{ll}
\mathrm{V} & =\text { Validitas } \\
\mathrm{TSEV} & =\text { Total Skor Empirik Validitas } \\
\text { S-max } & =\text { Skor maksimal yang diharapkan }
\end{array}
$$

Sedangkan untuk kriteria validasi diklasifikasikan menjadi 4 kriteria. Kriteria validasi untuk media pembelajaran ini diadaptasi dari Akbar dan Sriwijaya (2010:212) seperti tampak pada Tabel 2.
Tabel 1 Kriteria Validitas

\begin{tabular}{|c|l|l|}
\hline No & Kriteria & \multicolumn{1}{|c|}{ Tingkat Validasi } \\
\hline 1 & $75,01 \%-100,00 \%$ & $\begin{array}{l}\text { Sangat valid ( dapat digunakan } \\
\text { tanpa revisi). }\end{array}$ \\
\hline 2 & $50,01 \%-75,00 \%$ & $\begin{array}{l}\text { Cukup valid (dapat digunakan } \\
\text { dengan revisi kecil). }\end{array}$ \\
\hline 3 & $25,01 \%-50,00 \%$ & $\begin{array}{l}\text { Tidak valid (tidak dapat } \\
\text { digunakan). }\end{array}$ \\
\hline 4 & $00,00 \%-25,00 \%$ & $\begin{array}{l}\text { Sangat tidak valid (terlarang } \\
\text { digunakan). }\end{array}$ \\
\hline
\end{tabular}

\section{PEMBAHASAN}

Pengembangan media pembelajaran diawali dengan proses analisis kebutuhan media pembelajaran. Analisis kebutuhan yang diperoleh diantaranya adalah (1) media pembelajaran berupa tayangan materi, (2) bentuk materi merupakan kombinasi dari teks, gambar, video, animasi dan lain-lain, (3) media pembelajaran yang variatif yang menggabungkan dari beberapa bentuk media, (4) media pembelajaran yang interaktif. Hasil analisis kebutuhan tersebut selanjutnya dijadikan dasar dalam pengembangan desain, materi dan bentuk materi pembelajaran..

\subsection{Bentuk Produk Media Pembelajaran}

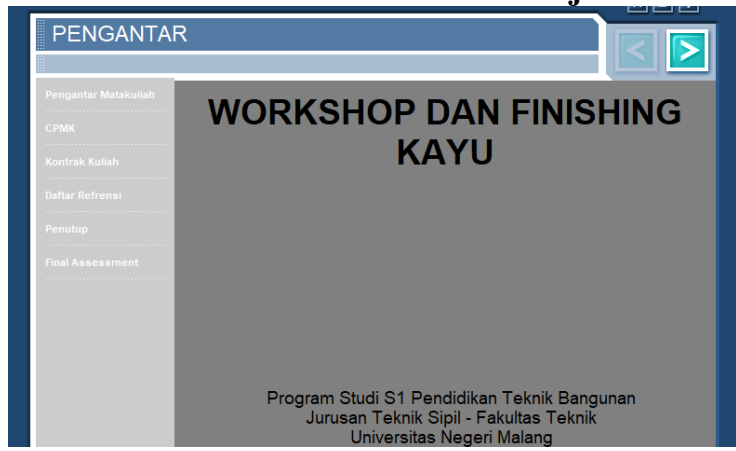

Gambar 2. Gambar Tampilan Awal Pengembangan dengan Software Lectora

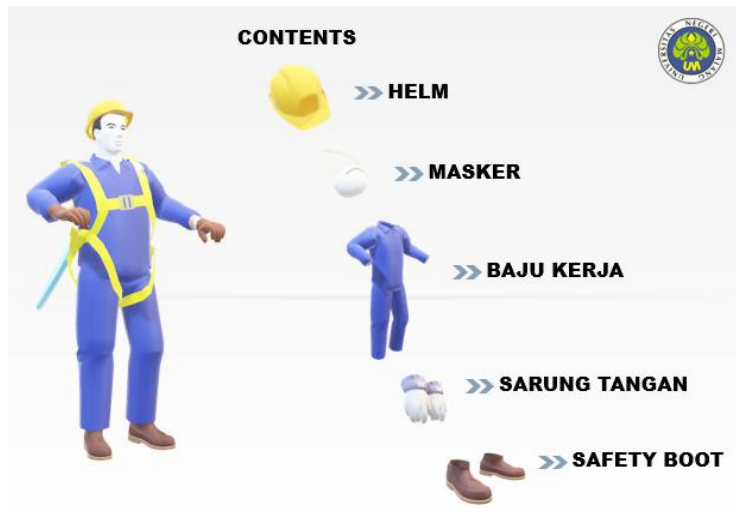

Gambar 3. Tampilan Pengenalain APD Workshop Kayu 
ISSN: 2503-071X

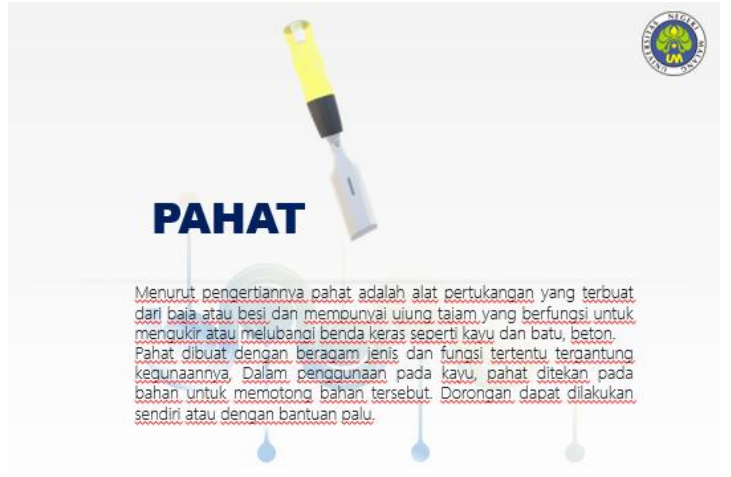

Gambar 4. Tampilan Materi Pengenalan Alat Kerja Tangan Manual

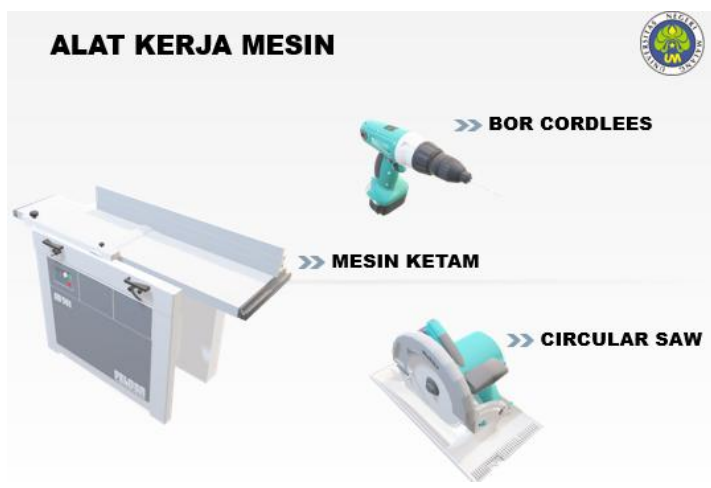

Gambar 5. Tampilan Pengenalan Alat Kerja Masinal

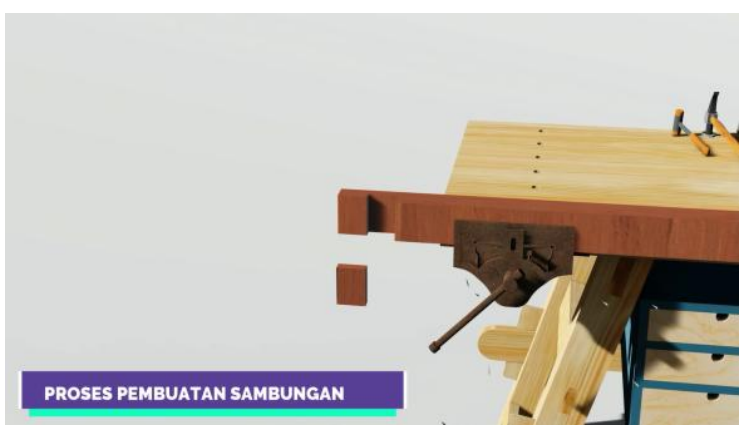

Gambar 6. Tampilan Video Animasi Pembuatan Sambungan

\subsection{Kelayakan Produk Media Pembelajaran}

Berdasarkan hasil uji validasi media yang secara keseluruhan diperoleh menunjukkan sangat valid dengan nilai prosentase $88,5 \%$ dari tigabelas aspek penilaian yang ditentukan, namun terdapat dua aspek seperti tampilan animasi dalam media pembelajaran dan kemudahan dalam pengoperasian media pembelajaran dengan prosentase $75 \%$ yang terkategorikan cukup valid, untuk aspek yang lainnya terkategorikan sangat valid.
Tabel 2. HasilValidasi Ahli Media

\begin{tabular}{|c|c|c|c|c|c|}
\hline \multirow[t]{2}{*}{ NO } & \multirow[t]{2}{*}{$\begin{array}{c}\text { ASPEK } \\
\text { PENILAIAN }\end{array}$} & \multicolumn{2}{|c|}{$\begin{array}{c}\text { SKOR } \\
\text { VALIDATO } \\
\text { R } \\
\end{array}$} & \multirow[t]{2}{*}{$\begin{array}{l}\text { RATA- } \\
\text { RATA }\end{array}$} & \multirow[t]{2}{*}{ KATEGORI } \\
\hline & & V1 & V2 & & \\
\hline 1. & Komunikatif & 3 & 4 & $87.5 \%$ & Sangat Valid \\
\hline 2. & $\begin{array}{l}\text { Kreatifitas } \\
\text { dalam } \\
\text { penuangan } \\
\text { gagasan }\end{array}$ & 4 & 4 & $100.0 \%$ & Sangat Valid \\
\hline 3. & $\begin{array}{l}\text { Kelogisan } \\
\text { penyajian } \\
\text { video animasi }\end{array}$ & 3 & 4 & $87.5 \%$ & Sangat Valid \\
\hline 4. & $\begin{array}{l}\text { Tampilan } \\
\text { animasi } \\
\text { dalam media } \\
\text { pembelajaran }\end{array}$ & 3 & 3 & $75.0 \%$ & Cukup Valid \\
\hline 5. & $\begin{array}{l}\text { Ketepatan } \\
\text { bahasa yang } \\
\text { digunakan } \\
\text { (sederhana } \\
\text { dan mudah } \\
\text { dipahami) } \\
\end{array}$ & 4 & 3 & $87.5 \%$ & Sangat Valid \\
\hline 6. & $\begin{array}{l}\text { Desain dan } \\
\text { pengaturan } \\
\text { warna } \\
\text { tampilan } \\
\text { media } \\
\text { pembalajaran }\end{array}$ & 4 & 3 & $87.5 \%$ & Sangat Valid \\
\hline 7. & $\begin{array}{l}\text { Penggunaan } \\
\text { tombol } \\
\text { interaktif } \\
\end{array}$ & 3 & 4 & $87.5 \%$ & Sangat Valid \\
\hline 8. & $\begin{array}{l}\text { Pengaturan } \\
\text { letak tombol } \\
\text { navigasi } \\
\text { (kemudahan } \\
\text { dalam } \\
\text { pengoperasian } \\
\text { media } \\
\text { pembelajaran) }\end{array}$ & 3 & 3 & $75.0 \%$ & Cukup Valid \\
\hline 9. & $\begin{array}{l}\text { Kejelasan } \\
\text { teks dalam } \\
\text { media } \\
\text { pembelajaran }\end{array}$ & 4 & 3 & $87.5 \%$ & Sangat Valid \\
\hline 10 & $\begin{array}{l}\text { Pemilihan } \\
\text { jenis dan } \\
\text { ukuran huruf }\end{array}$ & 4 & 4 & $100.0 \%$ & Sangat Valid \\
\hline 11. & $\begin{array}{l}\text { Transisi antar } \\
\text { slide }\end{array}$ & 3 & 4 & $87.5 \%$ & Sangat Valid \\
\hline 12. & $\begin{array}{l}\text { Kejelasan } \\
\text { petunjuk } \\
\text { penggunaan }\end{array}$ & 4 & 4 & $100.0 \%$ & Sangat Valid \\
\hline 13. & $\begin{array}{l}\text { Kemenarikan } \\
\text { media } \\
\text { pembelajaran } \\
\text { berbasis } \\
\text { animasi } \\
\text { secara } \\
\text { keseluruhan } \\
\text { (Tampilan } \\
\text { Media } \\
\text { keseluruhan) }\end{array}$ & 4 & 3 & $87.5 \%$ & Sangat Valid \\
\hline & TOTAL & 3.54 & 3.54 & $88.5 \%$ & $\begin{array}{l}\text { SANGAT } \\
\text { VALID }\end{array}$ \\
\hline
\end{tabular}

Hasil yang sama juga diperoleh pada uji validasi materi yaitu terkategorikan sangat valid dengan prosentase $85,0 \%$ dari duapuluh aspek penilaian yang ditentukan, namun terdapat tiga aspek seperti 
kejelasan tujuan pembelajaran dalam media pembelajaran, menumbuhkan rasa ingin tahu mahasiswa, dan kelogisan penyajian video animasi dalam media pembelajaran dengan prosentase $83,3 \%$ dan $75 \%$ berturut turut yang terkategorikan cukup valid dan untuk aspek lainnya terkategorikan sangat valid.

Tabel 3. Hasil Validasi Ahli Materi

\begin{tabular}{|c|c|c|c|}
\hline NO & ASPEK PENILAIAN & $\begin{array}{l}\text { RATA- } \\
\text { RATA }\end{array}$ & KATEGORI \\
\hline 1. & $\begin{array}{lr}\text { Kesesuaian } & \text { media } \\
\text { dengan } & \text { pencapain } \\
\text { tujuan pembelajaran }\end{array}$ & $83.3 \%$ & Sangat Valid \\
\hline 2. & $\begin{array}{ll}\text { Kejelasan } & \text { tujuan } \\
\text { pembelajaran } & \text { dalam } \\
\text { media pembelajaran }\end{array}$ & $83.3 \%$ & Cukup Valid \\
\hline 3. & $\begin{array}{lr}\text { Kesesuaian } & \text { materi } \\
\text { dengan } & \text { kurikulum } \\
\text { yang } & \text { berlaku } \\
\text { khususnya } & \text { kurikulum } \\
\text { di PT } & \\
\end{array}$ & $91.7 \%$ & Sangat Valid \\
\hline 4. & $\begin{array}{ll}\begin{array}{l}\text { Kejelasan isi } \\
\text { pada }\end{array} & \text { materi } \\
\text { pembelajaran } & \\
\end{array}$ & $91.7 \%$ & Sangat Valid \\
\hline 5. & $\begin{array}{lr}\text { Kesesuaian } & \text { materi } \\
\text { pada } & \text { media } \\
\text { pembelajaran } & \text { dengan } \\
\text { materi secara teori }\end{array}$ & $83.3 \%$ & Sangat Valid \\
\hline 6. & $\begin{array}{l}\text { Kedalaman (detail dan } \\
\text { lengkap) materi yang } \\
\text { ada dalam media } \\
\text { pembelajaran tersebut }\end{array}$ & $83.3 \%$ & Sangat Valid \\
\hline 7. & $\begin{array}{l}\text { Keruntutan materi } \\
\text { yang ada dalam media } \\
\text { pembelajaran tersebut }\end{array}$ & $166.7 \%$ & Sangat Valid \\
\hline 8. & $\begin{array}{l}\text { Apakah materi yang } \\
\text { disampaikan dengan } \\
\text { bermacam-macam } \\
\text { bentuk } \\
\text { (kalimat,gambar dan } \\
\text { video animasi) sudah } \\
\text { layak? }\end{array}$ & $91.7 \%$ & Sangat Valid \\
\hline 9. & $\begin{array}{l}\text { Media tersebut dapat } \\
\text { mengembangkan } \\
\text { kemampuan personal } \\
\text { mahasiswa dalam } \\
\text { belajar }\end{array}$ & $83.3 \%$ & Sangat Valid \\
\hline 10. & $\begin{array}{l}\text { Media tersebut dapat } \\
\text { mengembangkan } \\
\text { kemampuan akademik } \\
\text { mahasiswa dalam } \\
\text { belajar }\end{array}$ & $91.7 \%$ & Sangat Valid \\
\hline 11. & $\begin{array}{l}\text { Media tersebut dapat } \\
\text { mengembangkan } \\
\text { kemampuan } \\
\text { psikomotorik } \\
\text { mahasiswa dalam } \\
\text { belajar } \\
\end{array}$ & $83.3 \%$ & Sangat Valid \\
\hline 12. & $\begin{array}{l}\text { Menumbuhkan rasa } \\
\text { ingin tahu mahasiswa }\end{array}$ & $75.0 \%$ & Cukup Valid \\
\hline 13. & $\begin{array}{ll}\text { Media } & \text { tersebut } \\
\text { memudahkan } & \\
\text { mahasiswa } & \text { dalam } \\
\text { memahami } & \text { materi } \\
\text { proyeksi. } & \\
\end{array}$ & $83.3 \%$ & Sangat Valid \\
\hline
\end{tabular}

\begin{tabular}{|c|c|c|c|}
\hline NO & ASPEK PENILAIAN & $\begin{array}{l}\text { RATA- } \\
\text { RATA }\end{array}$ & KATEGORI \\
\hline 14. & 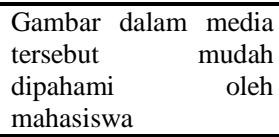 & $83.3 \%$ & Sangat Valid \\
\hline 15. & $\begin{array}{lr}\begin{array}{l}\text { Kemudahan } \\
\text { pemahaman }\end{array} & \text { video } \\
\text { animasi } & \text { oleh } \\
\text { mahasiswa } & \\
\end{array}$ & $83.3 \%$ & Sangat Valid \\
\hline 16. & $\begin{array}{l}\text { Kejelasan tayangan } \\
\text { video animasi dalam } \\
\text { media pembelajaran }\end{array}$ & $83.3 \%$ & Sangat Valid \\
\hline 17. & $\begin{array}{l}\text { Kelogisan penyajian } \\
\text { video animasi terhadap } \\
\text { materi pembelajaran }\end{array}$ & $75.0 \%$ & Cukup Valid \\
\hline 18. & $\begin{array}{l}\text { Kemampuan } \\
\text { memotivasi mahasiswa } \\
\text { untuk merespon pesan } \\
\text { yang tersampaikan } \\
\text { melalui media } \\
\end{array}$ & $91.7 \%$ & Sangat Valid \\
\hline 19. & $\begin{array}{lr}\text { Kemenarikan } & \text { media } \\
\text { pembelajaran } & \text { berbasis } \\
\text { animasi } & \text { secara } \\
\text { keseluruhan } & \\
\end{array}$ & $83.3 \%$ & Sangat Valid \\
\hline 20. & $\begin{array}{lr}\text { Kecocokan } & \text { media } \\
\text { pembelajaran } & \text { berbasis } \\
\text { animasi } & \text { untuk } \\
\text { digunakan di sipejar }\end{array}$ & $91.7 \%$ & Sangat Valid \\
\hline & TOTAL & $89.2 \%$ & $\begin{array}{l}\text { SANGAT } \\
\text { VALID }\end{array}$ \\
\hline
\end{tabular}

Berdasarkan penilaian kelayakan oleh para ahli secara keseluruhan menunjukkan hasil yang valid sehingga media ini dapat dilanjutkan untuk diujicobakan pada pembelajaran terkhusus materi workshop dan finishing kayu sebagai media interkatif pendukung pemahaman mahasiswa.

\section{KESIMPULAN}

Berdasarkan Hasil penelitian pengembangan media pembelajaran, dapat disimpulkan beberapa hal diantaranya:

a. Media pembelajaran yang dikembangkan dalam bentuk tayangan materi dengan Main software menggunakan Lectora. Adapun sub materi yang dikembangkan yaitu berupa gambar dan video animasi

b. Hasil Validasi Ahli Materi menunjukkan hasil validitas materi yaitu terkategorikan sangat valid dengan prosentase $85,0 \%$.

c. Hasil Validasi Ahi Media menunjukkan hasil validitas media sebesar $88,5 \%$ yang terkategori sangat valid.

d. Media pembelajaran ini dapat digunakan sebagai resources untuk konten pembelajaran dengan menggunakan SIPEJAR. 


\section{PUSTAKA}

Arsyad, 2002. Media Pembelajaran. Jakarta: Rajawali Pers.

Heinich, Molenda dan Rusell, 1982. Instructional Media and The New Technologies of Intruction. New York: John Wiley \& Sons.

Ibrahim, Said Maulana. 2018. Tantangan Pendidikan Era Revolusi Industri 4.0. https://um.ac.id/content/page/2/2018/11/tantanga n-pendidikan-erarevolusi-industri-4-0.

Ibrahim. (2014). Klasifikasi dan Karakteristik Media Pembelajaran. Diakses tanggal 6 Juni 2020.

M. Faris Islami. (2018). "Tinjauan Kelayakan Ruang, Peralatan, dan Kondisi Fasilitas Bengkel Program Keahlian Konstruksi Kayu di SMK Negeri 2 Lubuk Basung". CIVED ISSN:23023411 (Vol. 5., No. 3).

Mas'ud Muhammad, Membuat Multimedia Pembelajaran dengan Lectora, Yogyakarta: Shonif, 2012.

Nurani. (2003). Modul Strategi Pembelajaran, Jakarta: Universitas Terbuka.

Omodara O.D. dan Adu E.I. Relevance of Educational Media and Multimedia Technology for Effective Service Delivery in Teaching and Learning Processes. IOSR Journal of Research \& Method in Education (IOSR-JRME). Volume 4, Issue 2 Ver. I (Mar-Apr. 2014), PP 48-51.

Permendiknas Nomor 40 tahun 2008, Aturan Mengenai Standar Sarana dan Prasarana yang arus Dipenuhi Pada Setiap Jurusan yang Ada pada Lembaga Pendidikan SMK/MAK secara umum.

Purwanti, Puput. (2018). 10 Kriteria dalam menentukan media pembelajaran yang tepat. Artikel. www.pakarkomunikasi.com. Diakses 8 Juni 2020.

Purwono. Joni, dkk. (2014). Penggunaan Media Audio-Visual Pada Mata Pelajaran Ilmu Pengetahuan Alam di Sekolah Menengah Pertama Negeri 1 Pacitan. Dalam Jurnal Teknologi Pendidikan dan Pembelajaran Vol. 2, No. 2: 127

Pusat Bahasa Indonesia. (2001). Kamus Besar Bahasa Indonesia, edisi ke-3. Jakarta: Balai Pustaka.

Rosmayanti, H.P. (2010). Mengenal Ilmu Komunikasi. Bandung: Widya Padjajaran.

Sadiman dkk, 1996. Media Pendidikan: Pengertian, Pengembangan dan Pemanfaatannya. Jakarta: PT Raja Grafindo Persada.

Sugiyono. (2010). Metode penelitian pendidikan (pendekatan kuantitatif, kualitatif, dan R\&D). Bandung: Alfabeta.

Sumberharjo Putra, dkk. (2015). Media Pembelajaran Pengenalan Huruf dan Angka Di Taman Kanak-Kanak Tunas. Dalam Journal Speed -Sentra Penelitian Engineering dan Edukasi - Volume 7 No. 3.24
Suprayekti, Anggreini Dwi. (2017). Pelaksanaan Program Workshop "Belajar Efektif" untuk orang tua. Universitas Negeri Jakarta.

Willy, Deny. 2005. Pengantar Praktik Bengkel Mebel. Institut Teknologi Bandung

Wiyono, K. (2015). Pengembangan Multimedia Interaktif Pembelajaran Teori Kinetik Gas Berbantuan Lectora Inspire untuk Siswa Sekolah Menengah Atas (SMA). Jurnal Inovasi dan Pembelajaran Fisika, 2(2), 211-219.

Zuhri, M. S., \& Rizaleni, E. A. (2016). Pengembangan Media Lectora Inspire dengan Pendekatan Konstektual pada Siswa SMA Kelas X. Jurnal Inovasi dan Pembelajaran Fisika, 5(2), 113-119. 